4. Радбиль Т. Б. Переводимость как феномен межъязыкового взаимодействия. Логический анализ языка. Перевод художественных текстов в разные эпохи. Москва: Индрик, 2012). С. 7-12.

5. Ретуева Л. М. Семантическая напряженность художественного прозаического произведения (на материале романов А. Мэрдок и М. Дрэббл): автореф. дис. ... канд. филол. наук: 10.02.04. Одесса, 1988. $16 \mathrm{c}$.

6. Шехтман Н. А. Семантическая напряженность текста и его понимание. Вестник Челябинского государственного педагогического университета. 2013. № 12. С. 166-173.

7. Coetzee J. M. Disgrace. London: Vintage, 2011. 220 p.

8. Lörscher, W. Translation Performance, Translation Process, and Translation Strategies. A Psycholinguistic Investigation. Gunter Narr, Tübingen, $1991.307 \mathrm{p}$.

DOI https://doi.org/10.30525/978-9934-26-073-5-2-27

\title{
МЕТОДИ ДОСЛІДЖЕННЯ БАГАТОЗНАЧНОСТІ
}

\author{
Кабаченко І. Л. \\ доиент кафедри перекладу \\ Національного технічного університету «Дніпровська політехніка» \\ м. Дніпро, Украӥна
}

Стрімкий розвиток науки і техніки, що спостерігається в Україні, як і у всьому світі, кожного дня спричиняе впровадження нових понять та термінів у різні сфери мови. Проте проблемою лишається те, що розуміти терміни стає дедалі важче. Ця проблема зумовлена по перш за все багатозначністю термінів. Тож оскільки саме багатозначність або полісемія $\epsilon$ основним компонентом, що призводить до нерозуміння значень слів людьми, іiі вивчення заслуговує особливе місце у мовознавстві.

Полісемія (грецьк. polysemos - багатозначний) - це наявність у мовної одиниці декількох значень. Лексична полісемія - це здатність одного слова означати різні предмети та явища дійсності. Для прикладу розглянемо два іменника. 
Таблиця 1.1

\begin{tabular}{|c|c|c|c|}
\hline $\begin{array}{l}\text { Англійський } \\
\text { іменник }\end{array}$ & Значення & $\begin{array}{c}\text { Німецький } \\
\text { іменник }\end{array}$ & Значення \\
\hline «field» & $\begin{array}{l}\text { має наступні лексичні } \\
\text { значення: } \\
\text { 1) поле, луг, великій } \\
\text { простір; } \\
\text { 2) родовище; } \\
\text { 3)спортивний } \\
\text { майданчик; } \\
\text { 4) поле бою; } \\
\text { 5) поле дії; } \\
\text { 6)галузь, сфера } \\
\text { діяльності та ін. }\end{array}$ & «das Feld» & $\begin{array}{c}\text { має наступні } \\
\text { лексичні значення: } \\
\text { 1) поле; } \\
\text { 2) нива, рілля; } \\
\text { 3) поле даних, зона } \\
\text { пам`яті; } \\
\text { 4) графа, } \\
\text { клітинка та ін. }\end{array}$ \\
\hline
\end{tabular}

Те лексичне значення, у якому виступає слово, визначається його сполучуваністю із іншими словами: «diamond-field», «field theory», «magnetic field», «field hockey», «to leave the field» (анг.); «elektrisches Feld», «etw. ins Feld führen», «etw. ins Feld führen» (нім.).

Між значеннями багатозначного слова існує певний зв язок, що дає можливість вважати їх значеннями одного слова

Здатність слова мати декілька значень вважається однією 3 мовних універсалій. Лексична полісемія обумовлена, з одного боку, безмежністю зовнішнього світу як сукупності предметів і явищ, а 3 іншого боку, обмеженістю словникового запасу навіть найрозвиненішої мови.

Лексична полісемія ставить перед дослідниками декілька серйозних теоретичних і практичних проблем. По словах В. В. Виноградова, «ці труднощі виникають в типових для тлумачних словників безперестанних змішеннях значень і вживань слова, в розпливчатості меж між значеннями і відтінками значень слова, в постійних розбіжностях у питаннях про кількість значень слова і правильності ïх визначення» [1, с. 169].

Вирішення питань, пов'язаних 3 лексичною полісемією, складає істотну частину будь-якого лексикографічного проекту масштабу словника. Наукове обгрунтування принципів і способів розмежування омонімів, значень слова, відтінків значень закладає і основи подальшого лексикографічного опису кожної виділеної одиниці.

Хоча навіть в деяких сучасних лексикографічних виданнях цей метод, мабуть, є основним, з середини 20 століття були запропоновані ряд підходів, спрямованих на формалізацію i, в деяких випадках, автоматизацію досліджень полісемії. 
Існуючі сучасні методи вивчення полісемії можна звести до чотирьох груп: контекстологічні, структурні, психолінгвістичні $\boldsymbol{i}$

\section{статистичні.}

Контекстологічний аналіз заснований на ретельному, хоча і не строго формальному аналізі тексту. У найбільш закінченому виді контекстологічна теорія представлена в роботах Н.Н. Амосової. Центральним поняттям в цій теорії $€$ «вказівний мінімум», який може бути лексичним, синтаксичним і лексико-синтаксичним, а також одно- i багаточленним. Аналіз елементів, що становлять вказівний мінімум, дозволяє виділити «контекстуальний набір», допустимий в межах одного значення даного слова, що реалізовується семантично.

У рамках цієї теорії розрізняється змінний і постійний контекст. Змінний контекст, у свою чергу, розпадається на лексичний і синтаксичний. Лексичний контекст визначається як «контекст, що містить такий вказівний мінімум, який сприяє реалізації значення слова за допомогою самої семантики того, що становить цей вказівний мінімум слова або комплексу слів» [2, с. 34].

Під синтаксичним розуміється такий контекст, вказівним мінімумом в якому служить сама синтаксична конструкція, елементом якої $є$ слово, що семантично реалізовується, незалежно від лексичних значень слів, що входять в цю конструкцію.

Основною проблемою при застосуванні контекстологічного аналізу в лексикографії $\epsilon$ необхідність визначення складу контекстуальних наборів, в яких реалізується те або інше значення слова, і відсутність формальних методів їх виділення. Відсутність загальноприйнятої «теорії підкласів слів» призводить до того, що суб'єктивне розширення або звуження зони охоплення окремого контекстуального набору обумовлює розчленовування семантичного континууму на менше або більше число сегментів. Прикладом цього явища служить розбіжність числа значень одного і того ж слова в різних словниках.

Серед проблем загальної лексикології, пов язаних із використанням контекстологічного аналізу, по перш за все можна назвати зняття неоднозначності лексичних одиниць у тексті. У контексті міститься уся необхідна інформація для однозначного розуміння висловлення, при цьому усі елементи контексту інформативні - структура словосполучення, граматична форма слова, семантика слів, що поєднуються та порядок послідовності елементів.

При перекладі текстів часто виникають проблеми із вибором слів через полісемію іноземної мови. Контекст грає важливу роль при виборі потрібного значення. Контекстуальні значення виникають під час 
використання слів при мовленні, в залежності від оточення, i реалізуються під впливом вузького, широкого та екстралінгвістичного контекстів [3, с. 173].

В межах загального поняття контексту розрізняється вузький контекст («мікроконтекст») i широкий контекст («макроконтекст»). Під вузьким контекстом мається на увазі контекст речення, тобто лінгвістичні одиниці, що становлять оточення цієї одиниці в межах речення. Під широким контекстом розуміють мовне оточення цієї одиниці, що виходить за рамки речення; це - текстовий контекст, тобто сукупність мовних одиниць, що оточують цю одиницю в межах, що лежать поза реченням, іншими словами, в суміжних 3 ним реченнях. Точні рамки широкого контексту вказати не можна - це може бути контекст групи речень, абзацу, глави або навіть усього твору (напр., розповіді або роману) в цілому [3, с. 174].

Разом з цим нерідко мають місце випадки, коли навіть максимально широкий контекст не містить в собі ніяких вказівок відносно того, в якому саме значенні вживається в даному випадку та або інша полісемантична одиниця i, отже, який еквівалент має бути вибраний в даному випадку при перекладі. У цих випадках для отримання необхідної інформації потрібний вихід за межі мовного контексту і звернення до екстралінгвістичної ситуації. Під «ситуацією» мається на увазі, поперше, ситуація спілкування, тобто ті обставини, в яких здійснюється комунікативний акт; по-друге, предмет повідомлення, тобто обставини (сукупність фактів), що описується в тексті; по-третє, учасники комунікації [2, с. 176]. Іноді в цьому випадку говорять про « екстралінгвістичний контекст» або про «контекст ситуації» (термін Дж. Ферса).

Запропоновані в 70-ті роки психолінгвістичні методи аналізу лексичної семантики зробили крок у бік об'єднання формального i суб'єктивного підходів. Так, асоціативна методика заснована на підрахунку частотності слів-реакцій, що виникають у інформантів у відповідь на слова-стимули. Вона дозволяе 3 певною мірою відтворюваності результатів встановити частоту вживання слова в тому або іншому значенні, відмежувати головне значення від другорядних, встановити специфіку функціонування багатозначного слова в тій або іншій підмові. За допомогою психометричних методів став можливим безпосередній вимір семантичної відстані між лексико-семантичними варіантами, актуалізованими в тому або іншому контексті. Окрім можливості формалізації таких понять як омонімія, полісемія та однозначність, психометричні методи дозволяють строгіше констатувати приналежність окремих елементів до тих або інших контекстуальних наборів. 
Явище полісемії включає дуже багато аспектів і вимагає набагато глибшого дослідження, тому необхідно підкреслити, що питання створення комплексного підходу до вивчення такого явища в лексикології як полісемія представляється цікавим і особливо злободенним нині в зв'язку із величезною кількістю багатозначних слів в різних мовах.

\title{
Лiтература:
}

1. Виноградов В.В. Основные типы лексических значений слова. Избранные труды: Лексикология и лексикография. Москва: 1977. C. $162-169$.

2. Амосова Н. Н. Фразеология английского языка. Москва: Ленинградский. университет, 1963.98 с.

3. Бархударов Л. С. Язык и перевод (вопросы общей и частной теории перевода). Москва: Международные. отношения, 1975. 275 с.

DOI https://doi.org/10.30525/978-9934-26-073-5-2-28

\section{PSYCHOLINGUISTIC ASPECT AS THE LATEST AND SIGNIFICANT COMPONENT OF MODERN TRANSLATION STUDIES}

\author{
Karachova D. V. \\ Candidate of Philological Sciences, \\ Senior Lecturer at the Department \\ of Business Foreign Language and Translation \\ National Technical University «Kharkiv Polytechnic Institute»
}

\section{Prytychenko H. V.}

Lecturer at the Department of Business Foreign Language and Translation National Technical University "Kharkiv Polytechnic Institute» Kharkiv, Ukraine

Psycholinguistics, as a scientific field, appeared not so long ago, in the twentieth century, but has already brought some scientific achievements.

The topic of psycholinguistic studies is quite relevant and each day it is more and more in demand so many scientists work in this field of linguistic research. Among modern scholars who work in this sphere of translation we can mention such names as Kovshikov V.A. [1], Leontiev A.A. [2], 